\title{
Angiogenesis in bone tissue engineering
}

\author{
Michaela Bienert* \\ IFLb Laboratoriumsmedizin Berlin GmbH, Berlin Germany \\ Institute of Molecular and Cellular Anatomy, RWTH University Hospital, Aachen, Germany
}

Blood vessel formation is described by two distinct mechanisms called vasculogenesis and angiogenesis [1]. During vasculogenesis, the first primitive vascular plexus and the heart form inside the developing embryo and new blood vessels arise out of mesodermal-derived hemangioblasts. Angiogenesis is defined as the formation of new blood vessels out of the existing vasculature in order to support vascular network expansion and remodelling. Network expansion is based on endothelial cell proliferation, migration and tube formation [2]. Since the passive transport by diffusion of oxygen and nutrients is limited by tissue thickness, a blood vessel is necessary every $100-200 \mu \mathrm{m}$ to support active nutrient supply and waste product removal [3]. Tissue supply with nutrients through blood vessels is not only important for organ homeostasis, it is also necessary for tissue regeneration and wound healing, which are important elements addressed in bone tissue engineering (BTE). Bone is an adult tissue that has the ability to heal itself when a specific size is not exceeded (so called critical size defect). However, the healing can be disturbed, making bone reconstruction after trauma impossible. Reconstructive surgical therapies currently use autologous, allogeneic and synthetic materials to fill the bone defects [4]. Autologous bone replacement is the gold standard in term of osteoinduction and osteoconduction. A disadvantage is that it is only available in limited amounts and in addition to the surgical intervention for defect reconstruction an additional surgery is required to obtain the autologous bone from the patient [5]. In comparison to autologous grafts, allografts are available in much higher quantities and shapes. However, they have a lower osteoinductivity compared to autologous grafts, which can lead to worse healing compared to autologous grafts. Thus, synthetic grafts like for example ceramics, metals or polymers are considered for BTE [5-7]. In contrast to autologous grafts, synthetic grafts do not provide the cellular elements necessary for osteogenesis and therefore exhibit lower osteoinductivity than autologous bone substitutes [8]. Since decades, insufficient vascularization hinders the translation of engineered bone constructs into the clinics. In addition, support of a bone environment rich in vascular networks is important for the tissue integration and its functionality after bone graft implantation [9] underlining the important role of angiogenesis and endothelial cells in BTE. Approaches discussed in the literature to increase vascularization include seeding cells on bone grafts and the control and guidance of vascular structure growth [10].

When the terms 'Bone tissue engineering', 'stem cells' and 'progenitor cells' are searched in Pubmed, endothelial progenitor cells (EPC) are described to be the most used cells in BTE along with mesenchymal stem cells (MSC), adipose-derived stem cells (ADMSC), and induced pluripotent stem cells (iPS) [4]. EPC are bone marrow-derived precursor cells which participate in the formation of new blood vessels and have the ability to differentiate into endothelial cells $[11,12]$. Since their isolation is possible from peripheral blood as an easily accessible cell source, they are attractive cells for BTE. In a segmental defect model, local EPC therapy enhanced bone regeneration significantly in comparison to a non-treated defect [13]. In a mouse calvarial defect model, human EPC derived from peripheral blood could augment vasculogenesis and osteogenesis. A sevenfold increase in blood vessel density, increased extra-cortical bone height and bone area fraction was detected after EPC transplantation in comparison to the control when $\beta$-tricalcium phosphate $(\beta$-TCP) biomaterials were used [14]. In a study which addresses regeneration in general, human umbilical vein endothelial cells (HUVEC) as a source for endothelial cells and MSC have been shown to have a promising regenerative potential. Cell mixtures of iPS cells, MSC and HUVEC condensate in vitro in so-called organ buds. The iPS cells were differentiated into mature specific cell types and added to the buds. When transplanted into organ defects for regeneration, these buds vascularized rapidly and exhibited a tissue-specific organization in a variety of tissues [15]. However, the colonization of a scaffold with cells also has limitations. If the cells are not autologously harvested, disease transmission and graft rejection can occur, making integration into the surrounding host tissue difficult. In contrast, when using autologous cells, the derived cell number might be insufficient to colonize an autologous graft. In addition, if a scaffold that was colonized with cells would enter a clinical trial, it would be classified as an advanced therapy medical product (ATMP). ATMP requirements and testing in clinical trials are described in regulation EC No. 1394/2007. The problem with translating ATMPs into clinical trials is that they are very different from classical medicine-based products, but the same GMP guidelines apply to them. The high variation occurring due to the use of primary cells is difficult to handle in this context [16]. A technique which is published and already used in humans is the AV loop technique [17].

A major hurdle in BTE remains to control and guide spatial vascular growth in materials. Vascular endothelial growth factor (VEGF) is the best studied angiogenic factor and is used in many BTE settings. Materials have been engineered to achieve sustained and tailored delivery profiles [10]. VEGF incorporation into $\beta$-TCP increased invasion of microvasculature and osseointegration in a murine calvarial defect [18]. VEGF incorporation into a poly lacticco-glycolic acid (PLGA) scaffold showed increased vessels infiltration in a rat calvarial defect compared to scaffolds without VEGF [19]. Hollow channels can be fabricated by many different approaches like silicon molds, electrospinning, laser drilling and 3D fiber deposition. Inside hollow channels endothelial cells can grow in a directed manner within an impenetrable material [20]. In an elegant approach, different VEGF gradients where created in hydrogels which are penetrable by

${ }^{\star}$ Correspondence to: Michaela Bienert, IFLb Laboratoriumsmedizin Berlin GmbH, Berlin Germany, E-mail: michaela.bienert@rwth-aachen.de

Received: Septenber 25, 2018; Accepted: October 18, 2018; Published: October 24,2018 
endothelial cells. It has been demonstrated that not the availability of VEGF in general, but the different VEGF gradient concentrations guide vascular tube formation [20,21]. Besides, different oxygen levels were included into engineered tissue, resulting in different VEGF expression levels in this tissue [22]. Since new bone formation is dependent on a time-dependent balance between vascularization and bone formation some approaches investigated the effects of temporal cascades of dual growth factors release through the use of specifically engineered biomaterials. The authors describe a setup which allows for a quick release of VEGF, initiating a vasculogenic response, followed by a slow release of bone morphogenic protein-2 (BMP2) in PLGA microparticles. In a subcutaneous model increased ectopic bone formation and increased blood vessel volume was detected with this controlled release approach compared to single VEGF or BMP2 releasing scaffolds [23].

Cell seeding on bone grafts, hollow channel building, gradient modulation and growth factor addition are promising approaches to stimulate cells to produce growth factors necessary for the environment in which the construct will be implanted. BTE strategies combined with stem and progenitor cell implementation have an impact on regenerative medicine and reduce patient morbidity.

\section{References}

1. Clark NC, Pru CA, Pru JK (2017) Novel Regulators of Hemodynamics in the Pregnant Uterus. Prog Mol Biol Transl Sci 145: 181-216. [Crossref]

2. Patan S (2004) Vasculogenesis and angiogenesis. Cancer Treat Res 117: 3-32. [Crossref]

3. Jain RK, Au P, Tam J, Duda DG, Fukumura D (2005) Engineering vascularized tissue. Nat Biotechnol 23: 821-823. [Crossref]

4. Tevlin R, Walmsley GG, Marecic O, Hu MS, Wan DC, et al. (2016) Stem and progenitor cells: advancing bone tissue engineering. Drug Deliv Transl Res 6:159-173. [Crossref]

5. Neovius E, Engstrand T (2010) Craniofacial reconstruction with bone and biomaterials: review over the last 11 years. J Plast Reconstr Aesthet Surg 63: 1615-1623. [Crossref]

6. Wang W, Yeung KWK (2017) Bone grafts and biomaterials substitutes for bone defect repair: A review. Bioact Mater 2: 224-47. [Crossref]

7. Kanczler JM, Oreffo RO (2008) Osteogenesis and angiogenesis: the potential for engineering bone. Eur Cell Mater 15: 100-114. [Crossref]

8. Nasr HF, Aichelmann-Reidy ME, Yukna RA (1999) Bone and bone substitutes. Periodontol 2000 19: 74-86. [Crossref]
9. Mercado-Pagan AE, Stahl AM, Shanjani Y, Yang Y (2015) Vascularization in bone tissue engineering constructs. Ann Biomed Eng 43: 718-29. [Crossref]

10. García JR, García AJ (2016) Biomaterial mediated strategies targeting vascularization for bone repair. Drug Deliv Transl Res 6: 77-95. [Crossref]

11. Asahara T, Murohara T, Sullivan A, Silver M, van der Zee R, et al. (1997) Isolation of putative progenitor endothelial cells for angiogenesis. Science 275: 964-7. [Crossref]

12. Atesok K, Matsumoto T, Karlsson J, Asahara T, Atala A, et al. (2012) An emerging cell-based strategy in orthopaedics: endothelial progenitor cells. Knee Surg Sports Traumatol Arthrosc 20: 1366-1377. [Crossref]

13. Atesok K, Li R, Stewart DJ, Schemitsch EH (2010) Endothelial progenitor cells promote fracture healing in a segmental bone defect model. J Orthop Res 28: 10071014. [Crossref]

14. Zigdon-Giladi H, Michaeli-Geller G, Bick T, Lewinson D, Machtei EE (2015) Human blood-derived endothelial progenitor cells augment vasculogenesis and osteogenesis. $J$ Clin Periodontol 42: 89-95. [Crossref]

15. Takebe T, Enomura M, Yoshizawa E, Kimura M, Koike H, et al. (2015) Vascularized and Complex Organ Buds from Diverse Tissues via Mesenchymal Cell-Driven Condensation. Cell Stem Cell 16: 556-565. [Crossref]

16. Hartmann-Fritsch F, Marino D, Reichmann E (2016) About ATMPs, SOPs and GMP: The Hurdles to Produce Novel Skin Grafts for Clinical Use. Transfus Med Hemother 43: 344-52. [Crossref]

17. Leibig N, Wietbrock JO, Bigdeli AK, Horch RE, Kremer T, et al. (2016) FlowInduced Axial Vascularization: The Arteriovenous Loop in Angiogenesis and Tissue Engineering. Plast Reconstr Surg 138: 825-835. [Crossref]

18. Wernike E, Montjovent MO, Liu Y, Wismeijer D, Hunziker EB, et al. (2010) VEGF incorporated into calcium phosphate ceramics promotes vascularisation and bone formation in vivo. Eur Cell Mater 19: 30-40. [Crossref]

19. Leach JK, Kaigler D, Wang Z, Krebsbach PH, Mooney DJ (2006) Coating of VEGF-releasing scaffolds with bioactive glass for angiogenesis and bone regeneration. Biomaterials 27: 3249-3255. [Crossref]

20. Rouwkema J, Khademhosseini A (2016) Vascularization and Angiogenesis in Tissue Engineering: Beyond Creating Static Networks. Trends Biotechnol 34: 733-45. [Crossref]

21. Odedra D, Chiu LLY, Shoichet M, Radisic M (2011) Endothelial cells guided by immobilized gradients of vascular endothelial growth factor on porous collagen scaffolds. Acta Biomater 7: 3027-3035. [Crossref]

22. Cheema U, Brown RA, Alp B, MacRobert AJ (2007) Spatially defined oxygen gradients and vascular endothelial growth factor expression in an engineered 3D cell model. Cell Mol Life Sci 65: 177. [Crossref]

23. Young S, Patel ZS, Kretlow JD, Murphy MB, Mountziaris PM, et al. (2009) Dose effect of dual delivery of vascular endothelial growth factor and bone morphogenetic protein-2 on bone regeneration in a rat critical-size defect model. Tissue Eng Part A 15: 2347-2362. [Crossref]

Copyright: (C2018 Bienert M. This is an open-access article distributed under the terms of the Creative Commons Attribution License, which permits unrestricted use, distribution, and reproduction in any medium, provided the original author and source are credited. 